Article

\title{
Sustainable Production of 5-Hydroxymethylfurfural from Pectin-Free Sugar Beet Pulp in a Simple Aqueous Phase System-Optimization with Doehlert Design
}

\author{
Hanna Pińkowska ${ }^{1}$, Małgorzata Krzywonos ${ }^{2, *}{ }^{\mathbb{C}}$, Paweł Wolak ${ }^{1}$, Przemysław Seruga ${ }^{2}{ }^{\oplus}$, \\ Agata Górniak ${ }^{3}\left[{ }^{10}\right.$, Adrianna Złocińska ${ }^{3}$ and Michał Ptak ${ }^{4}$ \\ 1 Department of Industrial Chemistry, Wrocław University of Economics and Business, Komandorska 118/120, \\ 53-345 Wrocław, Poland; hanna.pinkowska@ue.wroc.pl (H.P.); pawel.wolak@ue.wroc.pl (P.W.) \\ 2 Department of Bioprocess Engineering, Wrocław University of Economics and Business, \\ Komandorska 118/120, 53-345 Wrocław, Poland; przemyslaw.seruga@ue.wroc.pl \\ 3 Laboratory of Elemental Analysis and Structural Research, Wrocław Medical University, Borowska 211A, \\ 50-556 Wrocław, Poland; agata.gorniak@umed.wroc.pl (A.G.); adrianna.zlocinska@umed.wroc.pl (A.Z.) \\ 4 Department of Economics and Research on Development, Wrocław University of Economics and Business, \\ Komandorska 118/120, 53-345 Wrocław, Poland; michal.ptak@ue.wroc.pl \\ * Correspondence: malgorzata.krzywonos@ue.wroc.pl
}

Received: 22 September 2020; Accepted: 27 October 2020; Published: 28 October 2020

\begin{abstract}
Waste solid residue from the hydrothermal extraction of pectin derived from sugar beet pulp was used as feedstock in the production of 5-hydroxymethylfurfural (5-HMF). The depolymerization of pectin-free sugar beet pulp (PF-SBP) to monosaccharides and their dehydration to 5-HMF were conducted in subcritical water using a batch reactor. The experimental design methodology was used in order to model the hydrothermal process and to optimize the operational parameters of the reaction, namely temperature and holding time. These parameters are required to achieve the highest yield of 5-HMF. The model predicts, in good agreement with experimental results $\left(R^{2}=0.935\right)$, an optimal yield of 5-HMF (of approximately $38 \%$ in relation to the cellulosic fraction content in the PF-SBP) at a temperature of $192.5^{\circ} \mathrm{C}$ and a holding time of about $51.2 \mathrm{~min}$. 5-HMF was successfully isolated from the reaction mixture using the liquid-liquid extraction method. The results are suitable for industrial upscaling and may become an incentive to introduce a new, environmentally friendly, uncomplicated, and efficient waste treatment method. The method would be used to treat products from the sugar refining industry, the treatment of which has proven to be problematic until now.
\end{abstract}

Keywords: pectin-free sugar beet pulp; subcritical water; 5-hydroxymethylfurfural; experimental design methodology; bioeconomy; biorefinery; biowaste

\section{Introduction}

5-hydroxymethylfurfural is an aromatic compound, which has a structure of furan, and which contains both formyl and hydroxy-methyl functional groups [1]. The 5-HMF can be obtained via catalytic hydroxymethylation of 2-furfural (2-FA) using formaldehyde [2,3]. It can also be obtained via dehydration of all types of $\mathrm{C} 6$ carbohydrates, both monomeric and polymeric, e.g., in the process of the conversion of cheap and widely available renewable resources, which are rich in the polysaccharide fraction, such as agricultural and forestry residues and food waste [4,5]. The hydrolysis of hemicellulosic, cellulosic and fructan-based biomass [6-9] leads directly to obtaining hexoses, including glucose and/or fructose, which are used in the process of dehydration to obtain 5-HMF. 
The transformation of biomass into 5-HMF has been extensively reviewed by many researchers [6-11]. The effective conversion of the polysaccharide fraction of the biomass to 5-HMF, which ensures the high efficiency and selectivity of the process as well as the minimization of the number of chemical reactions, and the number of stages of isolating and purifying the product, requires biomass pretreatment using physical and chemical pretreatment methods. These methods result in, among other things, decreasing cellulose crystallinity, and, in consequence, increasing product availability, using a complicated reaction system which comprises homogeneous or heterogenous oneor-multicomponent catalysts and a suitable aqueous, nonaqueous or mixed reaction system [7-9,12]. Despite the indisputable achievements in the field of technologies for the conversion of biomass into 5-HMF, it is still a challenge to ensure a highly productive and energy-efficient solution, but also to develop an efficient technical concept for large scale production, which would cause less harm to the environment [10].

The 5-HMF derived from renewable resources, which maintains in its structure six carbon atoms that were present in the original feedstock, is a valuable bio-based key platform chemical used to produce a wide variety of substances. So far, these have been derived from petrochemical raw materials-bulk and fine chemicals, such as monomers, pharmaceuticals, agrochemicals, flavors and fragrances, and the precursors of liquid fuels and blending components $[6,7,13,14]$.

Using bio-based 5-HMF to produce various intermediates, marketable products and energy is in line with the bioeconomy concept, and is an option to reduce dependence on exhaustible fossil resources [15]. However, finding new technologically feasible, economically viable and environmentally friendly ways to replace non-renewable resources with bioresources is still a significant challenge [16].

To develop a more sustainable society, it is also essential to use waste biomass, including agricultural residues and by-products, as biorefinery feedstocks [17]. Such a shift towards a circular economy model will help to reduce primary resource consumption and waste generation. [18]. Using low-cost biowaste streams as inputs to produce value-added products may lead to increased economic or social benefits in terms of local development or new jobs.

Taking into consideration the principles of green chemistry, the most promising and desirable method of biomass conversion involves its initial pretreatment and suitable hydrothermal conversion in hot liquid water $[9,14,19]$. This thermochemical process is sustainable-subcritical water is a cheap, widely available, inflammable and pure solvent, reagent and acid/alkaline catalyst. Its use minimizes or eliminates the need to use toxic reagents, catalysts and solvents, and it does not generate toxic waste $[20,21]$. In this field, the production of 5-HMF from real biomass rich in the polysaccharide fraction in hydrothermal conditions is presently one of the most interesting applications [14].

The objective of this research was to examine the production of 5-HMF from waste plant biomass rich in the cellulosic fraction in hydrothermal conditions, and its isolation from the reaction mixture. The solid post-extraction residue was the biomass raw material used for the conversion. The residue was obtained via the pretreatment of raw sugar beet pulp, which is a byproduct of the sugar refining industry. The pretreatment consisted of the hydrothermal extraction of the pectin fraction. According to our knowledge, there are no investigations devoted to the hydrothermal treatment of pectin-free sugar beet pulp leading to the formation of 5-HMF.

The hydrothermal conversion of PF-SBP was conducted in a simple autocatalytic aqueous phase system without the use of any additional catalysts or excipients. This system exploited the specific properties of subcritical water and used water as the reaction medium.

At the same time, an attempt was made to optimize the hydrothermal production of 5-HMF from PF-SBP by means of optimal experimental design (OED), using the quadratic model, which enables the presentation of a statistical model for the conversion and the estimation of its coefficients based on the numerical data obtained in the course of the experiments. The current research has determined the effect of the reaction parameters (temperature (T) and holding time $\left(t_{h}\right)$ ) on the yield of 5-HMF. 


\section{Materials and Methods}

\subsection{Materials and Chemicals}

Pectin-free sugar beet pulp was used for the purpose of this research. It constitutes a solid residue obtained via the hydrothermal extraction of pectin from sugar beet pulp [22].

Water, 2-FA and 5-HMF were provided from Sigma-Aldrich, and the remaining reagents were used for the purpose of the analytical determinations and were purchased from POCh (Gliwice, Poland). Depending on the analytical method used, the solvents and reagents were of analytical or HPLC grade and did not require further purification.

\subsection{Reactor and Experimental Procedure}

The PF-SBP, oven-dried to a constant mass at a temperature of $45^{\circ} \mathrm{C}$, was subjected to hydrothermal treatment, which was performed in the 4576A-type batch reactor (Parr Instrument Company, Moline, IL, USA). A thorough description of the reactor's equipment is published in a different paper [23].

An investigation into the hydrothermal treatment of $10 \mathrm{~g}$ of PF-SBP carried out in $190 \mathrm{~g}$ of water was conducted. A detailed description of the reactor equipment and the experimental procedure was published elsewhere [23].

The preliminary stage of the experiments included the examination of the effects of the reaction parameters-reaction temperature $\left(160-240^{\circ} \mathrm{C}\right)$ and holding time $(0-75 \mathrm{~min})$-on the production of 5-HMF. To determine the parameters of the studied process so as to determine an optimal yield of 5-HMF, the parameters established in the first step of the reaction-temperatures ranging from 180 to $220^{\circ} \mathrm{C}$ and duration (holding time) from 0 (the reaction was halted at the point when the intended temperature was reached) to $60 \mathrm{~min}$-were used in the experimental series, which utilized the optimal experimental design (OED) methodology (Doehlert array) [23].

In a given PF-SBP hydrothermal treatment, the combined influence of the reaction parameters, not only when the reaction mixture was maintained at the planned temperature, but also during the heat up and cool down periods, can be shown by introducing a severity factor $\left(\mathrm{R}_{0}\right)[24,25]$. Simultaneously, variations in temperature during heating and cooling periods were integrated into the overall reaction time $(\mathrm{t})$.

\subsection{Separation of Products of Pectin-Free Sugar Beet Pulp Hydrothermal Treatment}

A suspension containing water-soluble products (WS) and a water-insoluble solid post-reaction residue (WI) were obtained via the hydrothermal treatment of PF-SBP. The solid residue was separated from the liquid fraction by means of vacuum filtration using PTFE membrane filters (Sartorius, SRP 15, $0.45 \mu \mathrm{m})$. The WS fraction was diluted with water up to the volume of $250 \mathrm{~mL}$. In the WS fractions, the dry matter content (DM) was determined by evaporating water in a vacuum drier at $65^{\circ} \mathrm{C}$ down to dry matter.

The yields $\left(\mathrm{Y}_{\mathrm{i}}\right)$ of all the analyzed reaction products-the WS and WI fractions as well as the individual substances contained both in the WS and in the WI fractions-were calculated by means of the following equation (Equation (1)):

$$
\mathrm{Y}_{\mathrm{i}}\left(\mathrm{g} \cdot \mathrm{kg}^{-1}\right)=\left(\mathrm{m}_{\mathrm{i}} / \mathrm{m}_{\mathrm{PF}-\mathrm{SBP}}\right) \times 100
$$

where mi stands for the i-mass of the product $(\mathrm{g})$, and $\mathrm{m}_{\mathrm{PF}-\mathrm{SBP}}$ is the mass of PF-SBP used in the reaction $\left(\mathrm{kg}^{-1}\right)$.

The gaseous products of the rapeseed straw hydrothermal treatment were not collected.

\subsection{Isolation of 5-HMF}

5-HMF was isolated from the WS fractions using the liquid-liquid extraction method, described in detail by Liu et al. [26], in which binary mixture solvents were used to extract furfurals. The binary 
mixture solvents comprise 2-butanol-tetrahydrofuran (THF) with a volume ratio of 1:4. To improve the performance of the extraction, $20 \mathrm{wt}$. \% of $\mathrm{NaCl}$ was added to the organic solvents. The organic solvent $(50 \mathrm{~mL})$ was mixed with $50 \mathrm{~mL}$ of the WS fraction. The $\mathrm{pH}$ of the sample was adjusted by $0.5 \mathrm{M}$ $\mathrm{HCl}$ to $\mathrm{pH}=2$.4. The extraction mixture was manually shaken for $5 \mathrm{~min}$. Then the mixture was left for $30 \mathrm{~min}$. After the extraction, the organic phase was evaporated through a rotary evaporator to recover the organic solvent, and the concentrated, crude 5-HMF in the form of a viscous liquid was obtained.

Polyethyleneimine (PEI)—a soluble polyelectrolyte—was also used as a separation medium for removing the 5-HMF from the WS fractions [27]. The $50 \mathrm{~mL}$ of WS fraction was added to $105 \mathrm{~mL}$ of PEI $(50 \% \mathrm{w} / \mathrm{v})$. The polymer and adsorbed 5-HMF were separated from the sample using a $2 \mathrm{~mL}$ of sample in a 10,000 molecular weight cutoff centrifugal filter (ultrafiltration) and centrifuge spinning at $5000 \mathrm{rpm}$ for $30 \mathrm{~min}$. Next, the $1 \mathrm{~mL}$ of dilute sulfuric acid $(\mathrm{pH}=2.0)$ was added to the still containing the bound PEI and 5-HMF centrifugal filter. The filter and solution were centrifuged at $5000 \mathrm{rpm}$ for $30 \mathrm{~min}$. After separation, the ultrafiltration permeate contained the concentrated 5-HMF.

\subsection{Analyses and Analytical Methods}

The chemical composition of PF-SBP and the solid post-reaction residue were determined using methods typical for research on plant biomass [28-31], whereby the contents of nitrogen were determined by means of the Kjeldahl method, using a Turbotherm unit (Gerhardt Analytical Systems, Königswinter, Germany). The PF-SBP and the solid post-reaction residue, which were dried to a constant mass, underwent scientific investigation. The determination of the chemical composition was carried out in three repetitions. The paper presents an average value, which is based on the repetitions mentioned above.

The contents of 2-FA and 5-HMF in the WS fractions were directly determined using high-performance liquid chromatography (HPLC) at a temperature of $35^{\circ} \mathrm{C}$ in a Unisol-C18 column $(250 \mathrm{~mm} \times 4.6 \mathrm{~mm}$ i.d.) (Agela, Torrance, CA, USA). A diode array detector (DAD) at a wavelength of $290 \mathrm{~nm}$ was used to detect furfurals (Azura, Knauer, Berlin, Germany). A solution consisting of acetonitrile and solution $\mathrm{A}(2 \mathrm{~mL}$ acetic acid $+0.2 \mathrm{~mL}$ phosphoric acid, diluted with water up to $1 \mathrm{~L})$ at a volume ratio of 18:82 was used as the mobile phase. The flow rate of the mobile phase amounted to $1.2 \mathrm{~mL} \mathrm{~min}^{-1}$ [32]. Experimental errors amounted to $5 \%$.

The content of monosaccharides was determined by means of using an HPLC with an experimental error of $\pm 5 \%$, at a temperature of $40^{\circ} \mathrm{C}$ in a Phenomenex Luna Omega $3 \mu \mathrm{m}$ Sugar column (150 $\mathrm{mm} \times$ $4.6 \mathrm{~mm}$ id) equipped with a precolumn (SecurityGuard Cartridges SUGAR, $4 \times 3.0 \mathrm{~mm}$ ). A solution consisting of a volume fraction of acetonitrile $\varphi_{\text {acetonitrile }}=750 \mathrm{~mL} \mathrm{~L}^{-1}$ and water with a volume fraction of $\varphi_{\text {water }}=250 \mathrm{~mL} \mathrm{~L}^{-1}$ was used as the mobile phase. The flow rate of the mobile phase was $1.0 \mathrm{~mL} \mathrm{~min}^{-1}$. A refractometric (RI) detector (K-2301, Knauer, Berlin, Germany) was employed to detect saccharides.

\subsection{Modeling and Optimization Method}

Preliminary experiments on the hydrothermal treatment of PF-SBP indicated that $\mathrm{T}$ and $\mathrm{t}_{\mathrm{h}}$ had a significant influence on the 5-HMF yield contained in the WS fractions. The hydrothermal conversion of PF-SBP suggests complex reaction manifolds, the depolymerization of both hemicellulose and cellulose, yielding pentoses and hexoses, respectively, and the secondary dehydration reactions of primary products, leading to the formation of furfurals, including $5-\mathrm{HMF}[4,5,9,12,21]$. The product distribution changes notably depending on the variation of the used process parameters. The experimental design methodology (OED) was used to determine the experimental conditions (independent variables: $\mathrm{T}$ and $\left.t_{h}\right)$, ensuring optimal yields of 5-HMF $\left(\mathrm{Y}_{5-\mathrm{HMF}}\right)$ in the WS fractions of the PF-SBP hydrothermal conversion products. A detailed description of this methodology has been published elsewhere [33,34]. 


\section{Results and Discussion}

\subsection{Composition of Pectin-Free Sugar Beet Pulp}

The contents of the PF-SBP ash totaled (mean values and standard deviations, respectively) $60.1 \mathrm{~g} \cdot \mathrm{kg}^{-1} \pm 2.4 \mathrm{~g} \cdot \mathrm{kg}^{-1}$, total protein $104.4 \mathrm{~g} \cdot \mathrm{kg}^{-1} \pm 5.4 \mathrm{~g} \cdot \mathrm{kg}^{-1}$, hemicellulose $352.5 \mathrm{~g} \cdot \mathrm{kg}^{-1} \pm 3.8 \mathrm{~g} \cdot \mathrm{kg}^{-1}$, cellulose $199.7 \mathrm{~g} \cdot \mathrm{kg}^{-1} \pm 4.4 \mathrm{~g} \cdot \mathrm{kg}^{-1}$, and sulfuric acid-insoluble products including lignin $138.8 \mathrm{~g} \cdot \mathrm{kg}^{-1} \pm 9.3 \mathrm{~g} \cdot \mathrm{kg}^{-1}$.

\subsection{Effects of Hydrothermal Treatment on Pectin-Free Sugar Beet Pulp}

The preliminary stage of the experiments included an examination of the effect of the reaction parameters $\mathrm{T}\left(160-240^{\circ} \mathrm{C}\right)$ and $t_{\mathrm{h}}(0-75 \mathrm{~min})$ on the production of 5-HMF. In terms of material recovery and composition, the hydrothermal treatment of PF-SBP resulted in obtaining a wide variety of treated liquid product fractions and solid post-reaction residues.

Figure 1 presents the effects of both reaction temperature as well as holding time on the yield of 5-HMF in the WS fractions.

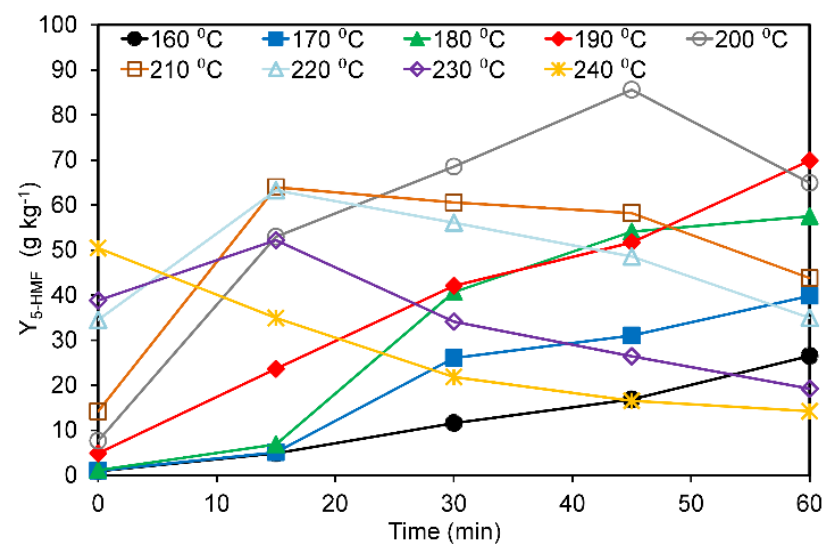

Figure 1. Effects of reaction temperature and time on the yield of 5-HMF contained in the WS fractions obtained from hydrothermal decomposition of PF-SBP.

5-HMF was present in all obtained fractions of WS, in the entire studied range of temperatures and holding times, whereby its productivity grew with the increase in temperature. At a constant temperature, it grew with the extension of holding time. The highest yield of 5-HMF, which was $85.6 \mathrm{~g} \cdot \mathrm{kg}^{-1}$, was a result of the reaction conducted at $200{ }^{\circ} \mathrm{C}$ and a $45 \mathrm{~min}$ holding time. Further extension of the holding time resulted in the degradation of 5-HMF and a drop in its productivity. In the following WS fractions, the productivity of 5-HMF reached its maximum value (for a given temperature) sooner as the temperature was rising - at $210^{\circ} \mathrm{C}$ after $30 \mathrm{~min}\left(60.6 \mathrm{~g} \cdot \mathrm{kg}^{-1}\right)$, at 220 and $230{ }^{\circ} \mathrm{C}$ after $15 \mathrm{~min}$ (respectively $63.3 \mathrm{~g} \cdot \mathrm{kg}^{-1}$ and $52.2 \mathrm{~g} \cdot \mathrm{kg}^{-1}$ ) and at $240{ }^{\circ} \mathrm{C}$ after a holding time of $0 \mathrm{~min}\left(50.5 \mathrm{~g} \cdot \mathrm{kg}^{-1}\right)$.

\subsection{Modeling of the Hydrothermal Treatment on Pectin-Free Sugar Beet Pulp, Using Optimal Experimental Design}

The rate of hydrolysis of pectin-free sugar beet pulp and the 5-HMF production conducted in hydrothermal conditions were affected most by reaction temperature and holding time. Based on the results obtained in the preliminary experiments, in the second phase of this study, the productivity of 5-HMF in the WS fractions underwent optimization. 5-HMF was a product of the dehydration of monosaccharides formed in the course of the hydrothermolysis of the cellulose contained in PF-SBP. In this experimental series, the reaction temperature was limited to the $180-220^{\circ} \mathrm{C}$ range. The holding time did not exceed $60 \mathrm{~min}$. The experimental region was examined using the Doehlert matrices, while reaction temperature and holding time were used as effective variables $\left(u_{i}\right)$. Applied reaction 
parameters, experimental points in the form of effective and normalized variables, and the results of the experiments carried out in the defined area are presented in Table 1.

Table 1. Doehlert matrices with effective $\left(\mathrm{u}_{\mathrm{i}}\right)$ and normalized $\left(\mathrm{x}_{\mathrm{i}}\right)$ variables and values of corresponding experimental responses $\left(\mathrm{Y}_{5-\mathrm{HMF}}\right)$ for the hydrothermal treatment of pectin-free sugar beet pulp.

\begin{tabular}{|c|c|c|c|c|c|c|c|}
\hline \multirow{2}{*}{ Experiment } & \multirow{2}{*}{$x_{1}$} & \multirow{2}{*}{$x_{2}$} & \multirow{2}{*}{$\begin{array}{c}\mathrm{u}_{1} \\
\mathrm{~T}\left({ }^{\circ} \mathrm{C}\right)\end{array}$} & \multicolumn{2}{|c|}{$\mathbf{u}_{2}$} & \multirow{2}{*}{$\begin{array}{c}Y_{5-\mathrm{HMF}^{-}}{ }^{\text {exp. }} \\
\left(\mathrm{g} \cdot \mathrm{kg}^{-1}\right)\end{array}$} & \multirow{2}{*}{$\begin{array}{l}\mathrm{Y}_{5-\mathrm{HMF}^{-\mathrm{cal}}}{ }^{(3)} \\
\left(\mathrm{g} \cdot \mathrm{kg}^{-1}\right)\end{array}$} \\
\hline & & & & $t_{h}(\min )$ & $t$ (min) & & \\
\hline 1 & +1 & 0 & 220 & 30 & 34.8 & 56.1 & 48.6 \\
\hline 2 & -1 & 0 & 180 & 30 & 31.8 & 40.5 & 48.0 \\
\hline 3 & +0.5 & +0.866 & 210 & 60 & 63.5 & 43.5 & 51.0 \\
\hline 4 & -0.5 & -0.866 & 190 & 0 & 3.1 & 4.5 & 1.4 \\
\hline 5 & +0.5 & -0.866 & 210 & 0 & 2.8 & 14.1 & 21.6 \\
\hline 6 & -0.5 & +0.866 & 190 & 60 & 62.1 & 82.5 & 75.0 \\
\hline 7 & 0 & 0 & 200 & 30 & 31.5 & 66.4 & 69.9 \\
\hline $7^{\prime(1)}$ & 0 & 0 & 200 & 30 & 32.4 & 74.9 & 69.9 \\
\hline $7^{\prime \prime}(1)$ & 0 & 0 & 200 & 30 & 31.8 & 68.5 & 69.9 \\
\hline
\end{tabular}

(1)-Experiments repeated at the center of the experimental region to calculate the standard deviation on the response: $s_{Y}=11.2\left(\mathrm{Y}_{5-\mathrm{HMF}}\right) .{ }^{(2)}$ —experimental values, ${ }^{(3)}$ —calculated values.

In the conducted series of optimization experiments, regardless of the applied reaction temperature, in a short holding time (experiments. 4,5), 5-HMF was obtained with low productivity. The temperature within the range of $190-200{ }^{\circ} \mathrm{C}$ and the long holding time had a positive effect on the production of 5-HMF (exps. 6, 7). An increase in reaction temperature to over $200^{\circ} \mathrm{C}$ (experiments. 1,3) led to a drop in productivity of 5-HMF in the WS fractions.

Low temperature and short holding time (exp. 2 and 4), as well as high temperature and long holding time (exp. 1 and 3), did not have a positive influence on obtaining a high productivity of 5-HMF. In the case of the low reaction temperature and short holding time, the applied parameters were insufficient to ensure the effective hydrolysis of the cellulose fraction contained in PF-SBP. In these reaction conditions, cellulose hydrolyzed slowly and the yields of 5-HMF were low [9]. However, when high temperature and long holding time were applied, monosaccharides, obtained as a result of the hydrolysis of the cellulose fraction, decomposed and underwent consecutive reactions $[9,14,21,35-37]$. In the conducted 5-HMF experiment series, the highest productivities, which were $82.5 \mathrm{~g} \cdot \mathrm{kg}^{-1}$ and $69.9 \mathrm{~g} \cdot \mathrm{kg}^{-1}$ (arithmetic mean of three measurements), were obtained respectively in experiment 6 and at the center of the experimental region (exps. $7,7^{\prime}$, and $7^{\prime \prime}$ ). The presence of hydronium and hydroxide ions (the increasing ionic product of water) in the applied experimental conditions and the investigated temperature range and holding time promoted the hydrolysis of the hemicellulose and cellulose contained in the PF-SBP into smaller molecules. It also aided the occurrence of secondary reactions, such as dehydration, which resulted in the production of 5-HMF.

Efforts to fit the experimentally determined 5-HMF yield into a quadratic model (Equation (2)) had positive results (predicted and experimental values are in agreement, within experimental errors). The below model was calculated using the multi-linear least square regression, based on the results of the experimental series:

$$
\mathrm{Y}_{5-\mathrm{HMF}}=69.96+0.29 \mathrm{x}_{1}+31 \mathrm{x}_{2}-21.66 \mathrm{x}_{1}^{2}-37.83 \mathrm{x}_{2}^{2}-28.1 \mathrm{x}_{1} \mathrm{x}_{2}
$$

In the experimental series, the standard error for coefficients $b_{0}, b_{1}$ and $b_{2}$ was 6.47 , for $b_{11}$ and $b_{22} 10.22$, and for $b_{12}$ it was 12.93 .

Two- (a) and three-dimensional (b) depictions of WS fraction $\mathrm{Y}_{5-\mathrm{HMF}}$ as a function of reaction temperature and holding time, which were calculated by means of the above models, are presented in Figure 2. The contour plots, which are shown in Figure 2a, represent the curves of the constant value of the approximate responses of $\mathrm{Y}_{5-\mathrm{HMF}}$ using the quadratic models. 
a)

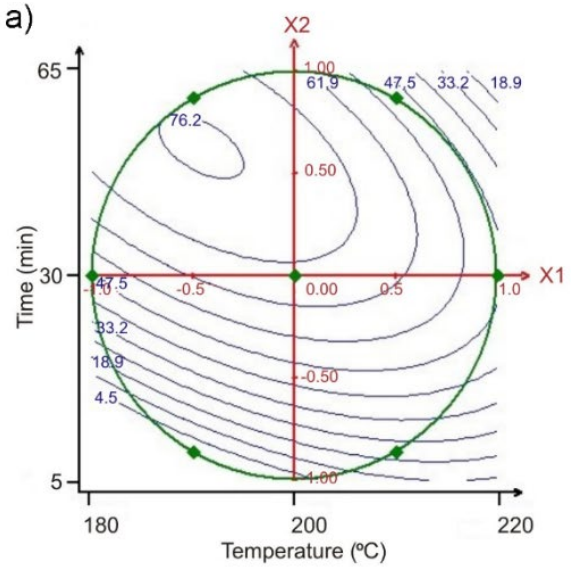

b)

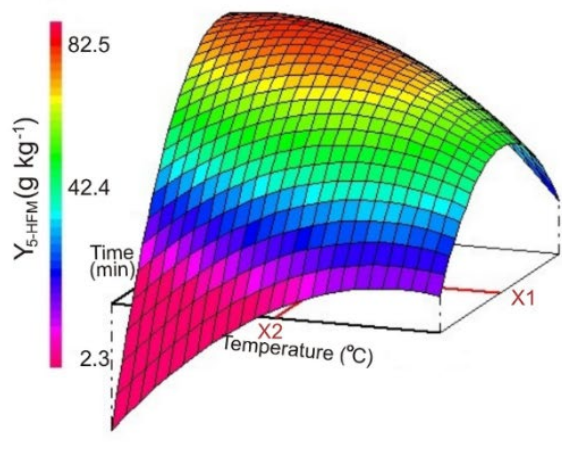

Figure 2. Two- (a) and three-dimensional (b) illustrations of the model for the yield of 5-HMF in the WS fractions presented as a temperature and holding time function in the course of the PF-SBP hydrothermal treatment.

The optimal range of hydrothermal production of 5-HMF from PF-SBP was achieved at the temperature range of $186.3-200.3^{\circ} \mathrm{C}$ and in the 57.9-39.2 $\mathrm{min}(\mathrm{t}=61.4-42.9 \mathrm{~min}$ ) holding time range. The highest estimated productivity of $5-\mathrm{HMF}, 76.1 \mathrm{~g} \cdot \mathrm{kg}^{-1}( \pm 9.6)$, was obtained at $192.5^{\circ} \mathrm{C}$ and in $51.2 \mathrm{~min}(\mathrm{t}=54.3 \mathrm{~min})$ of holding time, which was in good agreement with the experimental results $\left(R^{2}=0.935\right)$.

The obtained results are in relatively good agreement with the previous studies presented in the literature. A previous study reported a maximum 5-HMF yield of $46 \%$ from fructose at $220{ }^{\circ} \mathrm{C}$ and $30 \%$ from glucose at $240{ }^{\circ} \mathrm{C}$ in catalyst-free subcritical water for $10 \mathrm{~min}$ [38]. Promdej et al. reported on hydrothermal decomposition studies of glucose in sub- and supercritical water $\left(200-460^{\circ} \mathrm{C}, 25 \mathrm{MPa}\right)$ in a continuous setup [39]. The highest HMF yield (25\%) was obtained at $300^{\circ} \mathrm{C}$ and at residence times of $50-70 \mathrm{~s}$.

In the WS fraction obtained in the optimal experimental conditions, we also identified monosaccharides such as arabinose, xylose, mannose, and glucose, 2-FA and the dissolved protein fraction. The productivity of the sum of pentoses and hexoses was very low, at $3.9 \mathrm{~g} \cdot \mathrm{kg}^{-1}$. The yield of 2-FA was $61.7 \mathrm{~g} \cdot \mathrm{kg}^{-1}$ and of the dissolved protein was $5.3 \mathrm{~g} \cdot \mathrm{kg}^{-1}$.

\subsection{Isolation of 5-HMF from the Hydrozthermal Conversion of Aqueous Product Fractions}

The isolation of 5-HMF from the WS fraction obtained under optimal experimental conditions was conducted using a solvent extraction method. The solvent extraction technique, which utilizes organic solvents, is an often-used manner of separating and isolating 5-HMF from the aqueous phase. It is, however, not an easy process due to the fact that the distribution coefficient of 5-HMF between the organic and aqueous phase is not favorable [12]. To eliminate this issue, salt is introduced to the 5-HMF extraction by taking advantage of the "salt-out" effect. The addition of an inorganic salt to the aqueous phase containing 5-HMF improves the yield of its isolation by increasing the partitioning of 5-HMF into the extracting phase [40]. Additionally, keeping in mind the reactive nature of 5-HMF at high temperatures, low boiling point $(\mathrm{bp})$ solvents should be used for the purpose of the extraction [9].

In our work, we have utilized two solutions, which were developed to effectively remove 5-HMF from the waste plant biomass $[26,27]$. In the first option the used extractant was a traditional mixture of solvents consisting of 2-butanol (bp $100{ }^{\circ} \mathrm{C}$ )- $\mathrm{THF}$ (bp $66^{\circ} \mathrm{C}$ ), containing $20 \% \mathrm{wt}$. \% addition of $\mathrm{NaCl}$, and the second option used PEI as a separation medium.

After extraction with the 2-butanol-THF and $20 \mathrm{wt} . \% \mathrm{NaCl}$ mixture, the content of 5-HMF in the WS fraction decreased significantly, and after extraction amounted to $23.8 \mathrm{~g} \cdot \mathrm{kg}^{-1}$ ( $31.3 \%$ of the initial value). The subsequent evaporation of solvents from the 5-HMF-enriched organic phase allowed for the recovery of $5-\mathrm{HMF}$ with $100 \%$ efficiency and $72 \%$ purity. Simultaneously, after extraction, $86 \%$ of 
the applied organic solvents were recovered. The obtained results were close to the results presented in the paper by Liu et al. [26], which researched the usefulness of dichloromethane, 2-butanol, and tetrahydrofuran as single solvents and mixed solvents with different mixing ratios, and 5-HMF was subjected to extraction derived from simulated hydrothermal conversion products. 2-Butanol and THF, despite their relatively low boiling temperatures and satisfying extraction performance when compared to 5-HMF, are rarely used solvents, whereas methyl isobutyl ketone (MIBK) is an often-used, high boiling solvent (bp $118^{\circ} \mathrm{C}$ ), when compared to 5-HMF [41-43]. Sindermann et al. [42], to improve the results of the isolation of 5-HMF from the aqueous phase, used a countercurrent extraction process, which resulted in experimental yields of the extraction of up to $99 \%$ of 5-HMF. This 5-HMF extraction method was characterized by high efficiency, but is also an energy-intensive process [5]. In turn, in the work of Rihko-Struckmann et al. [43], the 5-HMF was recovered and separated from the aqueous phase (obtained in the course of mild liquefaction of algae residue remains after the extraction of $\beta$-carotene) by addition of MIBK. Experimentally, only $10.3 \mathrm{mg}$ of 5-HMF per gram of the remnant were recovered in the organic MIBK phase.

According to the second 5-HMF extraction procedure used in our paper, after the removal of 5-HMF using PEI, the content of 5-HMF in the WS fraction decreased to $35.4 \mathrm{~g} \cdot \mathrm{kg}^{-1}$ ( $46.5 \%$ of the initial value). The desorption of 5-HMF from the soluble adsorbent took place in consequence of using diluted sulfuric acid, and led to recovering 5-HMF with 58.3\% efficiency and with the purity of $85 \%$. The obtained results correspond well with the extraction results obtained by the other authors [27], who, by means of using PEI, separated organic acids and aldehydes such as 5-HMF from simple aqueous solutions. The authors reported recoveries of only 35\% of 5-HMF when PEI was stripped with pure water, while $97 \%$ of $5-\mathrm{HMF}$ recoveries were reported when sulfuric acid ( $\mathrm{pH} 2.0$ ) was used [44], whereby, after the separation of the PEI with 5-HMF, up to 59\% of HMF was recovered. Unfortunately, when PEI was used in order to detoxify ponderosa pine biomass slurry (after diluting acid pretreatment), the efficiency of the 5-HMF removal decreased considerably, probably due to the slurry containing residual wood solids and unfamiliar soluble components produced during enzymatic hydrolysis interfering with HMF removal [45].

\subsection{Composition of Product Fractions and Material Balance}

Yields of solid post-reaction residue, which remained after hydrothermal treatment of PF-SBP using OED, the contents of the unreacted hemicellulose, cellulose sulfuric acid insoluble products (including lignin), protein in the WI fractions, and the yields of WS fractions as well as gas fractions are summarized in Table 2.

Table 2. The yields of WI and WS fractions obtained in the experimental series using OED, and the contents of unreacted hemicellulose, cellulose, sulfuric acid-insoluble products and protein in solid post-reaction residues presented as a function of the severity index.

\begin{tabular}{|c|c|c|c|c|c|c|c|c|}
\hline \multirow{2}{*}{ Experiment } & \multirow{2}{*}{$\log R_{0}$} & \multirow{2}{*}{$\begin{array}{c}\mathrm{Y}_{\mathrm{WI}}{ }^{\mathrm{a}} \\
\left(\mathrm{g} \cdot \mathrm{kg}^{-1}\right)\end{array}$} & \multicolumn{4}{|c|}{ Content in the WI Fractions $\left(\mathrm{g} \cdot \mathrm{kg}^{-1}\right.$ ) } & \multirow{2}{*}{$\mathbf{Y}_{\mathrm{WS}}{ }^{b}$} & \multirow{2}{*}{$\begin{array}{c}\mathrm{Y}_{\mathrm{G}}{ }^{\mathrm{c}} \\
\left(\mathrm{g} \cdot \mathrm{kg}^{-1}\right)\end{array}$} \\
\hline & & & $H^{d}$ & $\mathrm{C}^{\mathrm{e}}$ & $L^{f}$ & $\mathbf{P}^{\mathrm{g}}$ & & \\
\hline 1 & 5.08 & 410.9 & 0.0 & 185.3 & 545.2 & 78.1 & 213.0 & 376.1 \\
\hline 2 & 3.86 & 453.1 & 18.2 & 229.2 & 429.2 & 87.5 & 330.9 & 216.0 \\
\hline 3 & 5.04 & 408.1 & 0.0 & 173.4 & 551.8 & 90.5 & 197.6 & 394.3 \\
\hline 4 & 3.14 & 518.9 & 89.1 & 241.6 & 361.3 & 115.8 & 358.0 & 123.1 \\
\hline 5 & 3.67 & 457.4 & 39.5 & 217.1 & 370.6 & 106.2 & 370.7 & 171.9 \\
\hline 6 & 4.44 & 456.3 & 3.8 & 209.7 & 529.6 & 92.6 & 243.8 & 299.0 \\
\hline $7^{\mathrm{h}}$ & 4.45 & 443.1 & 21.1 & 211.3 & 500.1 & 78.8 & 232.4 & 324.5 \\
\hline
\end{tabular}

${ }^{a}$ Yield of the WI fractions. ${ }^{b}$ Yield of the WS fractions. ${ }^{c}$ Yield of the gas product fractions. ${ }^{\mathrm{d}}$ Hemicellulose. ${ }^{\mathrm{e}}$ Cellulose.

${ }^{\mathrm{f}}$ Sulfuric acid insoluble components (including lignin). $\mathrm{g}$ Protein. ${ }^{\mathrm{h}}$ Mean values for 3 repeated experiments.

The conversion of cellulose is usually challenging owing to its stable crystalline structure constructed by extensive intra- and inter-molecular hydrogen bonds, as well as van der Waals 
interactions, and hydrophobic attraction [5]. However, in the feedstock applied in this research, the structure of PF-SBP as a product of the previous treatment (hydrothermal extraction of pectin) was disrupted. As a result, the solubilization and hydrothermolysis of its components were facilitated, were effective, and occurred under relatively mild reaction conditions. The yields of the resulting WI fractions, ranging from $408.11 \mathrm{~g} \cdot \mathrm{kg}^{-1}$ (exp. 3) to $518.9 \mathrm{~g} \cdot \mathrm{kg}^{-1}$ (exp. 4), decreased with the increase in temperature and extension of the holding time, and were a consequence of the solubilization and hydrothermolysis of hemicellulose and partial hydrothermolysis of the cellulose contained in the PF-SBP. On the other hand, hemicellulose was more susceptible to hydrothermal degradation, and its decomposition began faster and at a lower reaction temperature than the decomposition of cellulose $[36,37,46]$. The higher the temperature and the longer the holding time, the smaller the share of hemicellulose and cellulose in the WI fractions. The hemicellulose content dropped rapidly, and it was absent in the WI fractions obtained at the highest temperature and the longest holding time (exps. 1,3). In turn, cellulose content decreased gradually across the whole range of temperatures and holding times, and the part of cellulose initially contained in the PF-SBP was still present in all the obtained solid post-reaction residues.

Only a very small amount of hemicellulose was discovered in the WI fractions (severity index between 3.14 and 4.45). For $\log R_{\mathrm{o}}$ higher than 5 , hemicellulose was quantitatively removed from the solid post-reaction residues. The mutual dependence between unreacted cellulose and $\log R_{\mathrm{o}}$ was much less distinct. However, a decrease in contents of cellulose was a dominating tendency, which occurred along with an increase in cellulose $\log R_{0}$, especially above 5 .

Since hemicellulose and partial cellulose were depolymerized into soluble products, the solids from hydrothermal processing were enriched into lignin, the share of sulfuric acid-insoluble components increased with both the reaction temperature and holding time, and most of the lignin was still present in the WI fractions. Admittedly, according to some studies presented in the literature, a portion of lignin also undergoes solubilization and depolymerization [47,48]. However, the soluble fragments dissolve in water and/or undergoes re-condensation and repolymerization $[36,49]$. As a result, polymers and cross-linked phenolic char are created, and that, in turn, increases the content of sulfuric acid-insoluble components [50,51]. It is also likely that some other of the reactants, e.g., glucose and cellulose char [51,52], and other undesirable thermal decomposition products of components found in the reaction mixture, were present in the non-dissolved organic material obtained after sulfuric acid hydrolysis.

In turn, the hydrothermal decomposition of the protein present in the PF-SBP proceeded gradually along with an increase in both reaction temperature and holding time (exps. 1,3,4,6). Depolymerization was probably the primary transformation of the protein fraction, which led to amino acids [53], and subsequently, their thermal degradation is based on deamination and decarboxylation [53-55]. Moreover, Maillard's reaction could have taken place in the course of the hydrothermal transformation of PF-SBP, which is accompanied by amino groups of the created amino acids with carbonyl groups or hemiacetals of saccharides present in the reaction environment, which might have led to the formation of melanoidin [56].

The WI fraction could also contain insoluble humins—complex polyfuranic polymers, obtained as a result of the thermal degradation of low molecular weight production products [57].

The yield of the gaseous product fractions increased with the increases in both the temperature (exps. 1, 2, 4, 5, 7) and the holding time (exps. 3, 4, 5, 6).

Similarly to the development of the WN fraction's efficiency, the DM content in the WS fractions also decreased along with the temperature increasing (exps. 4,5) and the extension of the holding time (exps. 3, 6). Table 3 presents the yields of the chosen components in the WS fractions obtained from the hydrothermolysis of PF-SBP. After the solubilization and hydrothermolysis of hemicellulose and the partial hydrothermolysis of the cellulose contained in the PF-SBP, the resulting primary low-molecular products, i.e., pentoses and hexoses, as the reaction temperature increased and the holding time was extended, underwent many complicated, co-occurring, secondary transformations. 
Some examples of such reactions are dehydration, which led to furfurals including 5-HMF, as well as isomerization-transformation LBAE (Lobry de Bruyn-Alberda van Ekenstein) [37,58], retro-aldol condensation, intramolecular rearrangement [59-62], and finally gasification [60]. The yields of the gaseous product fractions increased as the temperatures (exps. 1, 2, 4, 5, 7) and holding times (exps. 3, $4,5,6)$ increased.

Table 3. Yield $\left(\mathrm{g} \cdot \mathrm{kg}^{-1}\right)$ of chosen components contained in the WS fractions obtained from hydrothermolysis of pectin free sugar beet pulp.

\begin{tabular}{cccccccc}
\hline \multirow{2}{*}{ Component } & \multicolumn{7}{c}{ Experiment } \\
\cline { 2 - 8 } & $\mathbf{1}$ & $\mathbf{2}$ & $\mathbf{3}$ & $\mathbf{4}$ & $\mathbf{5}$ & $\mathbf{6}$ & $\mathbf{7}^{\mathbf{a}}$ \\
\hline Pentoses & 0.5 & 2.9 & 0.1 & 3.1 & 2.6 & 1.1 & 1.2 \\
Hexoses & 6.7 & 2.6 & 5.6 & 1.9 & 3.2 & 2.5 & 3.5 \\
2-FA & 96.1 & 51.7 & 76.5 & 5.2 & 22.2 & 63.9 & 65.0 \\
5-HMF & 56.1 & 40.5 & 43.5 & 4.5 & 14.1 & 82.5 & 69.9 \\
Unidentified $^{b}$ & 53.6 & 233.2 & 71.9 & 343.3 & 328.6 & 93.8 & 92.8 \\
\hline
\end{tabular}

a Mean values for 3 repeated experiments. ${ }^{\mathrm{b}}$ Unidentified (U) calculated according to the equation $\mathrm{U}=$ mass of WS fraction minus mass of identified products present in the WS fraction.

The recorded yields of pentoses, as well as hexoses, were lower than the yield obtained in the course of traditional acid hydrolysis [63]. The hydrothermolysis of PF-SBP commenced with the solubilization and depolymerization of the hemicellulosic fraction and the concurrent cleavage of the acetyl groups, leading to the creation of pentoses as the main products [64]. Hexoses, which were the main products of the depolymerization of the cellulosic fraction, were detected as the reaction temperature increased. The increase in the ionic product of water $[65,66]$ within the examined temperature range promoted the hydrolysis of the hemicellulosic and cellulosic fractions. Increasing the reaction temperature and the holding time led to the decomposition of pentoses and hexoses, which degraded to, among others, 2-FA, and 5-HMF, respectively.

The mechanistic aspects of 5-HMF formation via the dehydration of hexoses are known and have been presented in an extensive and detailed manner in many review papers $[6,67,68]$. In general, three possible mechanisms have been proposed for the transformation of hexoses. The first and most widely discussed transformation involves the consecutive removal of three water molecules from corresponding hexoses to form 5-HMF. The second one is possible via the Maillard reaction of hexoses in the presence of amino acids and amines (originating from protein contained in PF-SBP). The third and most widely discussed route is the direct dehydration of hexoses to 5-HMF, which could take place via either acyclic intermediates or cyclic intermediates. It is important to emphasize that most of the mechanisms proposed earlier referred to the catalytic systems operating in aqueous conditions, and the reaction media could change the mechanism [68].

In the case of 5-HMF, the applied reaction conditions allow us to identify trends regarding productivity that is possible to achieve depending on the development of the value of the experiment's severity factor coefficient. The results obtained via experiments 2, 4, and 5 indicate that a severity factor lower than 4 is not conducive to obtaining high-productivity 5-HMF, and only increasing the factor to a value above 4 (exps. 1,3,6,7) allows the production of 5-HMF of satisfying productivity.

The results of the experiments indicate that the experiments conducted at lower reaction temperatures (exps. 2, 4) and/or at the shortest holding time (exps. 4, 5) resulted in the highest value of unidentified reaction products contained in the WS fractions. These products are likely to be related to the presence of xylo-oligosaccharides [48] and/or fragments of water-soluble oligomeric lignin $[21,64,69]$ and low molecular weight phenolic compounds formed by the partial hydrolysis of lignin contained in PF-SBP [21,64,69].

In the case of the remaining WS fractions obtained in the course of experiments, which were conducted at higher temperatures and/or longer holding times (experiments 1,3, 6,7), the content of the unidentified reaction products was significantly lower. However, their chemical compositions differed 
greatly from the compositions of the fractions obtained in experiments 2, 4, and 5 . In the applied reaction conditions, both pentoses and hexoses, as the quantitatively dominant primary products of depolymerization that originated from, respectively, hemicellulose and cellulose, contained in PF-SBP, underwent subsequent transformations. These transformations most probably led to the creation of subsequent secondary reaction products in the WS fractions, the contents of which were not determined in this work. Glyceraldehyde and glycolaldehyde were developed as a result of the retro-aldol condensation of pentose, while dihydroxyacetone and pyruvic aldehyde, respectively, were developed as a result of keto-enol tautomerization and the dehydration of glyceraldehyde [37]. As a result of the following transformations, FA (hydration, dehydration, tautomerization) in the WS fraction, formic acid, and levulinic acid could have been found there [70,71]. However, the specific contents of these reaction products were not determined in this study.

In turn, as a product of the dehydration of glucose, it was possible to obtain 1,6 -anhydro- $\beta$-Dglucose, and from it, acetic acid and lactic acid [70-72], as well as aldehydes and dihydroxyacetone as the subsequent secondary raw materials $[37,70,71]$.

Moreover, the co-occurring changes that the 5-HMF present in the WS fraction was subjected to, such as hydrolysis of the furan ring, tautomerization, aldol condensation and dehydration, could lead to the formation of carboxylic acids, benzenetriol and 2-FA [70,71].

Many research papers, the results of which were presented in numerous publications, in order to get around the problems related to the inhomogeneity and complexity of biomass, which also has an influence on the mechanism and the course of the process, concentrate on the synthesis of 5-HMF from simple model compounds, such as glucose and fructose. In the case of our research, the detailed mechanism of the hydrothermal treatment of components contained in the PF-SBP was challenging to study because the raw material can be converted into a substantial number of compounds, which may be obtained via different reaction pathways $[6,58,67,68,70,71]$.

\section{Conclusions}

In this study we investigated the production of 5-HMF from waste plant biomass rich in hemicellulose and cellulose components in subcritical water, using a simple autocatalytic aqueous phase system without the use of any additional catalyst and excipients. The study used solid post-extraction residue obtained as an outcome of the hydrothermal extraction of pectin from sugar beet pulp—a byproduct of the sugar refining industry—as a raw material.

Subcritical water technology is very complex. That is why the optimal experimental design methodology was selected to explain the dependence of the 5-HMF yield on the reaction temperature and holding time. The yields of 5-HMF reached the highest values, approximately $76.1 \mathrm{~g} \cdot \mathrm{kg}^{-1}$, at temperatures ranging from 186.3 to $200.3^{\circ} \mathrm{C}$, and holding times of $57.9-39.2 \mathrm{~min}$.

The isolation of 5-HMF from the WS fractions obtained under optimal experimental conditions was conducted using two liquid extractants (a mixture of 2-butanol-THF and PEI as a separation medium), which allowed us to successfully extract approximately $31.3 \%$ and $46.5 \%$ (respectively) of the initial 5-HMF value.

The 5-HMF obtained in the process of maximizing the value of both sugar beet pulp and pectin-free sugar beet pulp, corresponding to the concept of agro-bio-refineries, after isolation and appropriate physicochemical treatment, may be of commercial importance. It can be potentially used for various aims of industrial interest, such as in the production of chemicals, transportation fuels and energy.

Converting the pretreated pulp into value-added products may lead to some economic or environmental benefits, but the industrial production of biomass-derived 5-HMF and 5-HMF-based innovative derivatives still faces enormous challenges. Without a doubt, the greatest advantage of the 5-HMF method applied in our work is the low cost of the feedstock and the fact that it is universally available. Furthermore, the simplicity of the reaction system (the course of the 5-HMF synthesis in subcritical water without using any additional supplementary reagents) determines the indisputable advantages of this solution. The challenge that is still necessary to overcome is making a suitable 
choice of 5-HMF separation method and procedure for its purification. Additionally, the commercial feasibility and environmental impact, including greenhouse gas emissions, of the process and the production scheme should be studied more closely.

Based on the experimental results, it can be concluded that the application of subcritical water treatment in a process that does not require the use of acid may contribute to valorizing waste plant biomass, such as PF-SBP. This work provides an environmentally friendly method for the production and recovery of 5-HMF from waste plant biomass, and should help to facilitate further studies to develop a new process for the hydrothermal production of 5-HMF from waste biomass.

Author Contributions: H.P., P.W. and M.K. conceived and designed the experiments; H.P., P.W. performed the experiments; H.P., P.W., A.G., A.Z., data collection and analyses; H.P. and M.K. analyzed the data; H.P., M.K., P.S., M.P. prepared original draft; H.P. and M.K. reviewed and edited the manuscript. All authors have read and agreed to the published version of the manuscript.

Funding: H.P., M.K. and M.P. participation was partially financed by the Ministry of Science and Higher Education in Poland under the program "Regional Initiative of Excellence" 2019-2022 project number 015/RID/2018/19 total funding amount 10721 040,00 PLN.

Conflicts of Interest: The authors declare no conflict of interest. The funders had no role in the design of the study; in the collection, analyses, or interpretation of data; in the writing of the manuscript, or in the decision to publish the results.

\section{References}

1. Menegazzo, F.; Ghedini, E.; Signoretto, M. 5-hydroxymethylfurfural (HMF) production from real biomass. Molecules 2018, 23, 2201. [CrossRef]

2. Nishimura, S.; Shibata, A.; Ebitan, K. Direct hydroxymethylation of furaldehydes with aqueous formaldehyde over a reusable sulfuric functionalized resin catalyst. ACS Omega 2018, 3, 5988-5993. [CrossRef] [PubMed]

3. Nishimura, S.; Shibata, A. Hydroxymethylation of furfural to HMF with aqueous formaldehyde over zeolite beta catalyst. Catalysts 2019, 9, 314. [CrossRef]

4. Teong, S.P.; Yi, G.; Zhang, Y. Hydroxymethylfurfural production from bioresources: Past, present and future. Green Chem. 2014, 16, 2015-2026. [CrossRef]

5. Yu, I.K.M.; Tsang, D.C.W. Conversion of biomass to hydroxymethylfurfural: A review of catalytic systems and undergoing mechanisms. Bioresour. Technol. 2017, 238, 716-732. [CrossRef] [PubMed]

6. Van Putten, R.J.; Van der Waal, J.C.; De Jong, E.; Rasrenda, C.B.; Heeres, H.J.; De Vries, J.G. Hydroxymethylfurfural, a versatile platform chemical made from renewable resources. Chem. Rev. 2013, 113, 1499-1597. [CrossRef] [PubMed]

7. Zhang, Y.; Zhang, J.; Su, D. 5-Hydroxymethylfurfural: A key intermediate for efficient biomass conversion. J. Energy Chem. 2015, 24, 548-551. [CrossRef]

8. Rout, P.K.; Nannaware, A.D.; Prakash, O.; Kalra, A.; Rajasekhran, R. Synthesis of hydroxymethylfurfural from cellulose using green processes: A promising biochemical and biofuel feedstock. Chem. Eng. Sci. 2016, 142, 318-346. [CrossRef]

9. Perez, G.P.; Mukherjee, A.; Dumont, M.-J. Insights into HMF catalysis. J. Ind. Eng. Chem. 2019, 70, 1-34. [CrossRef]

10. Dutta, S.; De, S.; Saha, B. Advances in biomass transformation to 5-hydroxymethylfurfural and mechanistic aspects. Biomass Bioenergy 2013, 55, 355-369. [CrossRef]

11. Wang, H.; Zhu, C.; Li, D.; Liu, Q.; Tan, J.; Wang, C.; Cai, C.; Ma, L. Recent advances in catalytic conversion of biomass to 5-hydroxymethylfurfural and 2,5-dimethylfuran. Renew. Sustain. Energy Rev. 2019, 103, 227-247. [CrossRef]

12. Rosatella, A.A.; Simeonov, S.P.; Frade, R.F.M.; Afonso, C.A.M. 5-Hydroxymethylfurfural (HMF) as a building block platform: Biological properties, synthesis and synthetic applications. Green Chem. 2011, 13, 754-793. [CrossRef]

13. Addepally, U.; Thulluri, C. Recent progress in production of fuel liquid hydrocarbons from biomass-derived furanics via strategic catalytic routes. Fuel 2015, 159, 935-942. [CrossRef]

14. Kruse, A.; Dahmen, N. Hydrothermal biomass conversion: Quo vadis? J. Supercrit. Fluids 2018, 134, 114-123. [CrossRef] 
15. Attard, T.M.; Clark, J.H.; McElroy, C.R. Recent developments in key biorefinery areas. Curr. Opin. Green Sustain. Chem. 2020, 21, 64-74. [CrossRef]

16. González-García, S.; Gullón, B.; Moreira, M. Environmental assessment of Biorefinery processes for the valorization of lignocellulosic wastes into oligosaccharides. J. Clean. Prod. 2018, 172, 4066-4073. [CrossRef]

17. Da Silva, T.L.; Moniz, P.; Silva, C.; Reis, A. The dark side of microalgae biotechnology: A heterotrophic biorefinery platform directed to $\omega-3$ rich lipid production. Microorganisms 2019, 7, 670. [CrossRef] [PubMed]

18. Ubando, A.T.; Felix, C.B.; Chen, W.H. Biorefineries in circular bioeconomy: A comprehensive review. Bioresour. Technol. 2020, 299, 122585. [CrossRef]

19. Ruiz, H.A.; Conrad, M.; Sun, S.N.; Sanchez, A.; Rocha, G.J.M.; Romaní, A.; Castro, E.; Torres, A.; Rodríguez-Jasso, R.M.; Andrade, L.P.; et al. Engineering aspects of hydrothermal pretreatment: From batch to continuous operation, scale-up and pilot reactor under biorefinery concept. Bioresour. Technol. 2020, 299, 122685. [CrossRef]

20. Lachos-Perez, D.; Brown, A.B.; Mudhoo, A.; Martinez, J.; Timko, M.T.; Rostagno, M.A.; Forester-Carneiro, T. Applications of subcritical and supercritical water conditions for extraction, hydrolysis, gasification, and carbonization of biomass: A critical review. Biofuel Res. J. 2017, 14, 611-626. [CrossRef]

21. Knez, Ž.; Knez Hrnčič, M.; Čolnik, M.; Škerget, M. Chemicals and value added compounds from biomass using sub- and supercritical water. J. Supercrit. Fluids 2018, 133, 591-602. [CrossRef]

22. Pińkowska, H.; Krzywonos, M.; Wolak, P.; Złocińska, A. Pectin and neutral monosaccharides production from the simultaneous hydrothermal extraction of waste biomass from refining of sugar-Optimizatuion with the use of Doehlert design. Molecules 2019, 24, 472. [CrossRef] [PubMed]

23. Pińkowska, H.; Wolak, P.; Oliveros, E. Hydrothermolysis of rapeseed cake in subcritical water. Effect on reaction temperature and holding time on product composition. Biomass Bioenergy 2014, 64, 50-61. [CrossRef]

24. Overend, R.P.; Chornet, E.; Gascoigne, J.A. Fractionation of lignocellulosics by steam/aqueous pretreatments. Philos. T. R. Soc. Lond. 1987, A321, 523-536.

25. De Farias Silva, C.E.; Bertucco, A. Severity factor as an efficient control parameter to predict biomass solubilization and saccharification during acidic hydrolysis of microalgal biomass. Bioenergy Res. 2018, 11, 491-504. [CrossRef]

26. Liu, F.; Sivoththaman, S.; Tan, Z. Solvent extraction of 5-HMF from simulated hydrothermal conversion product. Sustain. Environ. Res. 2014, 24, 149-157.

27. Carter, B.; Gilcrease, P.C.; Menkhaus, T.J. Removal and recovery of furfural, 5-hydroxymethylfurfural, and acetic acid from aqueous solutions using a soluble cationic polyelectrolyte. Biotechnol. Bioeng. 2011, 108, 2046-2052. [CrossRef]

28. Undersander, D.; Mertens, D.R.; Thiex, N. Forage Analyses Procedures; The National Forage Testing Association: Omaha, NE, USA, 1993; p. 147. Available online: https://www.foragetesting.org/lab-procedures (accessed on 26 August 2020).

29. Sluiter, A.; Hames, B.; Ruiz, R.; Scarlata, C.; Sluiter, J.; Templeton, D. Report No. TP-510-42622; National Renewable Energy Laboratory: Golden, CO, USA, 2005; p. 8. Available online: https://www.nrel.gov/docs/ gen/fy08/42622.pdf (accessed on 26 August 2020).

30. Van Soest, P.J.; Robertson, J.B.; Lewis, B.A. Methods for dietary fiber, neutral detergent fiber, and nonstarch polysaccharides in relation to animal nutrition. J. Dairy Sci. 1991, 74, 3583-3597. [CrossRef]

31. Carrier, M.; Loppinet-Serani, A.; Denux, D.; Lasnier, J.M.; Ham-Pichavant, F.; Cansell, F.; Aymonier, C. Thermogravimetric analysis as a new method to determine the lignocellulosic composition of biomass. Biomass Bioenergy 2011, 35, 298-307. [CrossRef]

32. Alcazar, A.; Jurado, J.M.; Pablos, F.; Gonzalez, A.G.; Martin, M.J. HPLC determination of 2-furaldehyde and 5-hydroxymethyl-2-furaldehyde in alcoholic beverages. Microchem. J. 2006, 82, 22-28. [CrossRef]

33. Pińkowska, H.; Wolak, P.; Oliveros, E. Production of xylose and glucose from rapeseed straw in subcritical water-Use of Doehlert design for optimizing the reaction conditions. Biomass Bioenergy 2013, 58, 188-197. [CrossRef]

34. Ferreira, S.L.C.; Dos Santos, W.N.L.; Quitella, C.M.; Neto, B.B.; Bosque-Sendra, J.M. Doehlert matrix: A chemometric tool for analytical chemistry-Review. Talanta 2004, 63, 1061-1067. [CrossRef]

35. Wang, Z.W.; Zhu, M.Q.; Li, M.F.; Wang, J.Q.; Sun, R.C. Comprehensive evaluation of the liquid fraction during the hydrothermal treatment of rapeseed straw. Biotechnol. Biofuels 2016, 9, 142. [CrossRef] [PubMed] 
36. Yang, J.; He, Q.S.; Yang, L. A review on hydrothermal co-liquefaction of biomass. Appl. Energy 2019, 250, 926-945. [CrossRef]

37. Yu, Y.; Lou, X.; Wu, H. Some recent advances in hydrolysis of biomass in hot-compressed water and its comparisons with other hydrolysis methods. Energy Fuels 2008, 22, 46-60. [CrossRef]

38. Möller, M.; Harnisch, F.; Schröder, U. Microwave-assisted hydrothermal degradation of fructose and glucose in subcritical water. Biomass Bioenergy 2012, 39, 389-398. [CrossRef]

39. Promdej, C.; Matsumura, Y. Temperature effect on hydrothermal decomposition of glucose in sub- and supercritical Water. Ind. Eng. Chem. Res. 2011, 50, 8492-8497. [CrossRef]

40. Blumenthal, L.C.; Jens, C.M.; Ulbrich, J.; Schwering, F.; Langrehr, V.; Turek, T.; Kunz, U.; Leonhard, K.; Palkovits, R. Systematic identification of solvents optimal for the extraction of 5-hydroxymethylfurfural from aqueous reactive solutions. ACS Sustain. Chem. Eng. 2016, 4, 228-235. [CrossRef]

41. Ma, H.; Wang, F.; Yu, Y.; Wang, L.; Li, X. Autocatalytic production of 5-hydroxymethylfurfural from fructose-based carbohydrates in a biphasic system and its purification. Ind. Eng. Chem. Res. 2015, 54, 2657-2666. [CrossRef]

42. Sindermann, E.C.; Holbach, A.; Hahn, A.; Kockmann, N. Single phase coutercurrent extraction of 5-hydroxymethylfurfural from aqueous phase system. Chem. Eng. J. 2016, 283, 251-259. [CrossRef]

43. Rihko-Struckmann, L.K.; Molnar, M.; Pirwitz, K.; Fachet, M.; McBride, K.; Zinser, A.; Sundmacher, K. Recovery and separation of carbohydrate derivatives from the lipid extracted alga Dunaliella by mild liquefaction. ACS Sustain. Chem. Eng. 2017, 5, 588-595. [CrossRef]

44. Deng, F.; Aita, G.M. Detoxification of dilute ammonia pretreated energy cane bagasse enzymatic hydrolysate by soluble polyelectrolyte flocculants. Ind. Crops Prod. 2018, 112, 681-690. [CrossRef]

45. Carter, B.; Squillace, P.; Gilcrease, P.C.; Menkhaus, T.J. Detoxification of a lignocellulosic biomass slurry by soluble polyelectrolyte adsorption for improved fermentation efficiency. Biotechnol. Bioeng. 2011, 108, 2053-2060. [CrossRef]

46. Sharma, H.B.; Sarmah, A.K.; Dubey, B. Hydrothermal carbonization of renewable waste biomass for solid biofuel production: A discussion on process mechanism, the influence of process parameters, environmental performance and fuel properties of hydrochar. Renew. Sustain. Energy Rev. 2020, 123, 109761. [CrossRef]

47. Petersen, M.Ø.; Larson, J.; Thomsen, M.H. Optimization of hydrothermal pretreatment of wheat straw for production of bioethanol at low water consumption without addition of chemicals. Biomass Bioenergy 2009, 33, 834-840. [CrossRef]

48. Barbier, J.; Charon, N.; Dupassieux, N.; Loppinet-Serani, A.; Mahé, L.; Ponthus, J.; Courtiade, M.; Ducrozet, A.; Quoineaud, A.A.; Cansell, F. Hydrothermal conversion of lignin compounds. A detailed study of fragmentation and condensation reaction pathways. Biomass Bioenergy 2012, 46, 479-491. [CrossRef]

49. Ruiz, H.A.; Rodríguez-Jasso, R.M.; Fernandes, B.D.; Vicente, A.A.; Teixeira, J.A. Hydrothermal processing, as an alternative for upgrading agriculture residues and marine biomass according to the biorefinery concept: A review. Renew. Sustain. Energy Rev. 2013, 21, 35-51. [CrossRef]

50. Wahyudiono; Sasaki, M.; Goto, M. Recovery of phenolic compounds through the decomposition of lignin in near and supercritical water. Chem. Eng. Process. 2008, 47, 1609-1619. [CrossRef]

51. Ponnusamy, V.K.; Nagappan, S.; Bhosale, R.R.; Lay, C.H.; Nguyen, D.D.; Pugazhendhi, A.; Chang, S.W.; Kumar, G. Review on sustainable production of biochar through hydrothermal liquefaction: Physico-chemical properties and applications. Bioresour. Technol. 2020, 310, 123414. [CrossRef]

52. Fang, Z.; Minowa, T.; Smith, R.L.; Ogi, T.; Koziński, J.A. Liquefaction and gasification of cellulose with $\mathrm{Na}_{2} \mathrm{CO}_{3}$ and $\mathrm{Ni}$ in subcritical water at $350{ }^{\circ} \mathrm{C}$. Ind. Eng. Chem. Res. 2004, 43, 2454-2463. [CrossRef]

53. Rogalinski, T.; Herrmann, S.; Brunner, G. Production of amino acids from bovine serum albumin by continuous sub-critical water hydrolysis. J. Supercrit. Fluids 2005, 36, 49-58. [CrossRef]

54. Sato, N.; Quitain, A.T.; Kang, K.; Daimon, H.; Fujie, K. Reaction kinetics of amino acid decomposition in high-temperature and high-pressure water. Ind. Eng. Chem. Res. 2004, 43, 3217-3222. [CrossRef]

55. Sinağ, A.; Gülbay, S.; Uskan, B.; Canel, M. Biomass decomposition in near critical water. Energy Convers. Manag. 2010, 51, 612-620. [CrossRef]

56. Peterson, A.; Lachance, R.P.; Tester, J.W. Kinetic evidence of the Maillard reaction in hydrothermal biomass processing: Glucose-glycine interactions in high-temperature, high-pressure water. Ind. Eng. Chem. Res. 2010, 49, 2107-2117. [CrossRef] 
57. Yang, D.-P.; Li, Z.; Liu, M.; Zhang, X.; Chen, Y.; Xue, H.; Ye, E.; Luque, R. Biomass-derived carbonaceous materials: Recent progress in synthetic approaches, advantages, and applications. ACS Sustain. Chem. Eng. 2019, 7, 4564-4585. [CrossRef]

58. Peterson, A.A.; Vogel, F.; Lachance, R.P.; Fröling, M.; Antal, M.J.; Tester, J.W. Thermochemical biofuel production in hydrothermal media: A review of sub- and supercritical water technologies. Energy Environ. Sci. 2008, 1, 32-65. [CrossRef]

59. Lü, X.; Saka, S. New insights on monosaccharides' isomerization, dehydration and fragmentation in hot-compressed water. J. Supercrit. Fluids 2012, 61, 146-156. [CrossRef]

60. Kruse, A.; Funke, A.; Titiric, M.M. Hydrothermal conversion of biomass to fuels and energetic materials. Curr. Opin. Chem. Biol. 2013, 17, 515-521. [CrossRef]

61. Bayu, A.; Abudula, A.; Guan, G. Reaction pathways and selectivity in chemo-catalytic conversion of biomass-derived carbohydrates to high-value chemicals: A review. Fuel Process. Technol. 2019, 196, 106162. [CrossRef]

62. Wang, T.; Zhaia, Y.; Zhu, Y.; Li, C.; Zeng, G. A review of the hydrothermal carbonization of biomass waste for hydrochar formation: Process conditions, fundamentals, and physicochemical properties. Renew. Sustain. Energy Rev. 2018, 90, 223-247. [CrossRef]

63. Woiciechowski, A.L.; Neto, C.J.; de Souza Vandenberghe, L.P.; de Carvalho Neto, D.P.; Sydney, A.C.; Letti, L.A.; Karp, S.G.; Torres, L.A.; Soccol, C.R. Lignocellulosic biomass: Acid and alkaline pretreatments and their effects on biomass recalcitrance-Conventional processing and recent advances. Bioresour. Technol. 2020, 304, 122848. [CrossRef] [PubMed]

64. Cocero, M.J.; Cabeza, Á.; Abad, N.; Adamovic, T.; Vaquerizo, L.; Martínez, C.M.; Pazo-Cepeda, M.V. Understanding biomass fractionation in subcritical \& supercritical water. J. Supercrit. Fluids 2018, 133, 550-565.

65. Kruse, A.; Dinjus, E. Hot compressed water as reaction medium and reactant. Properties and synthesis reactions. J. Supercrit. Fluids 2007, 39, 362-380. [CrossRef]

66. Okolie, J.A.; Nanda, S.; Dalaia, A.K.; Berruti, F.; Kozinski, J.A. A review on subcritical and supercritical water gasification of biogenic, polymeric and petroleum wastes to hydrogen-rich synthesis gas. Renew. Sustain. Energy Rev. 2020, 119, 109546. [CrossRef]

67. Kang, S.; Fu, J.; Zhang, G. From lignocellulosic biomass to levulinic acid: A review on acid-catalyzed hydrolysis. Renew. Sustain. Energy Rev. 2018, 94, 340-362. [CrossRef]

68. Mika, L.T.; Cséfalvay, E.; Németh, A. Catalytic conversion of carbohydrates to initial platform chemicals: Chemistry and sustainability. Chem. Rev. 2018, 118, 505-613. [CrossRef]

69. Cheng, L.; Ye, X.P.; He, R.; Liu, S. Investigation of rapid conversion of switchgrass in subcritical water. Fuel Process. Technol. 2009, 90,301-311. [CrossRef]

70. Aida, T.M.; Sato, Y.; Watanabe, M.; Tajima, K.; Nonaka, T.; Hattori, H.; Arai, K. Dehydration of D-glucose in high temperature water at pressures up to $80 \mathrm{MPa}$. J. Supercrit. Fluids 2007, 40, 381-388. [CrossRef]

71. Aida, T.M.; Tajima, K.; Watanabe, M.; Saito, Y.; Kuroda, K.; Nonaka, T.; Hattori, H.; Smith, R.L.; Arai, K. Reactions of D-fructose in water at temperature up to $400{ }^{\circ} \mathrm{C}$ and pressures up to $100 \mathrm{MPa}$. J. Supercrit. Fluids 2007, 42, 110-119. [CrossRef]

72. Möller, M.; Nilges, P.; Harnisch, F.; Schröder, U. Subcritical water as reaction environment: Fundamentals of hydrothermal biomass transformation. ChemSusChem. 2011, 4, 566-579. [CrossRef]

Publisher's Note: MDPI stays neutral with regard to jurisdictional claims in published maps and institutional affiliations.

(C) 2020 by the authors. Licensee MDPI, Basel, Switzerland. This article is an open access article distributed under the terms and conditions of the Creative Commons Attribution (CC BY) license (http://creativecommons.org/licenses/by/4.0/). 